\title{
Dyeing Process and Mechanism of Eucalyptus Veneer with Pterocarpus macrocarpus Kurz Heartwood Pigment as Natural dye
}

\author{
Qingshuo Zhang, ${ }^{\mathrm{a}, *}$ Liuming Wei, ${ }^{\mathrm{a}}$ Yutong Yang, ${ }^{\mathrm{c}}$ Chan Luo, ${ }^{\mathrm{a}}$ Zhu Zhu, ${ }^{\mathrm{b}}$ Zhigao Liu, ${ }^{\mathrm{b}}$ \\ Yunlin $\mathrm{Fu},{ }^{\mathrm{a}}$ and Jing $\mathrm{Sun}^{\mathrm{a}, *}$
}

\begin{abstract}
To make full use of the processing residues of Pterocarpus macrocarpus Kurz and reduce the environmental pollution caused by synthetic dyes, natural dye was extracted from Dalbergia bariensis Pierre heartwood. The purpose of the work was to prepare natural dyes of Pterocarpus macrocarpus and identify the key color-producing components to better explore the mechanisms of combination between dyes and eucalyptus veneers. The main components of Pterocarpus macrocarpus heartwood were analyzed by ultra-high performance liquid chromatography with quadrupole-electrostatic field Orbitrap high resolution-mass spectrometry (UPLC-Q-EXACTIVE Orbitrap-MS). The best dyeing process and color fastness were measured. Research technology combining Fourier transform infrared spectroscopy (FTIR) and field emission scanning electron microscopy (FESEM) was used to explore the binding mechanism between eucalyptus veneers and dyestuffs. The UPLC-Q-EXACTIVE Orbitrap-MS results showed 16 flavonoids. The optimal dyeing process parameters of eucalyptus veneer were a $90{ }^{\circ} \mathrm{C}$ dyeing temperature, $12 \mathrm{~h}$ dyeing time, $4 \mathrm{wt} \%$ pigment, and $2 \mathrm{wt} \% \mathrm{NaCl}$. The FTIR and FESM results revealed that the dyeing was mainly achieved by physical adsorption and intermolecular hydrogen bonding.
\end{abstract}

Keywords: Pterocarpus macrocarpus Kurz; Wood dyeing; Natural dyes; Imitation mahogany;

Eucalyptus veneer

Contact information: a: College of Forestry, Guangxi University, Nanning, Guangxi 530000, China; b: School of resources, Environmental and Materials, Guangxi University, Nanning Guangxi 530000, China; c: Material science and Engineering School, Northeast Forestry University, Harbin, Heilongjiang 150040, China; *Corresponding authors: sunjing413@126.com; zhang_qing_shuo@163.com

\section{INTRODUCTION}

Rosewood is favored by most customers because of its high density, hardness, and unique wood style (Cao et al. 2003). With the improvement of people's living standards, the demand for rosewood products has increased. To meet the market demand, a substitute for rosewood is needed. In the context of the rapid development of modern forestry, eucalyptus has been widely planted because of its fast growth and high wood quality (Liu and Li 2010). However, the single color of eucalyptus greatly limits its value. Artificial dyeing of eucalyptus can improve its surface color and form more vivid patterns. Therefore, how to change the color of eucalyptus to increase its value has gradually attracted people's attention.

In the current research, most of the dyes used in wood dyeing are synthetic ones, which are relatively polluting during processing and pose a carcinogenic risk to the human body. The synthetic dyes are mostly azo dyes, and they can decompose with the formation of aromatic amine compounds that have carcinogenic effects on animals under reducing 
conditions (Ye et al. 2018). It has been found that humans (or animals) are stained with dyes after a close contact with azo dyestuffs for a long time. Especially when the dyeing fastness is poor, the dye molecules can migrate to human (or animal) skin and enter the body surface. Once they meet azo reductase secreted in the body, they are reduced to carcinogenic aromatic amine molecules. Among them, the aromatic amines of small molecules can penetrate the membrane of human (or animal) somatic cells and further metabolize to produce nitrogen positive ions in the human (or animal) body. Nitrogen positive ions attack the nuclear DNA of the cell as a strong electrophile and render normal cells cancerous (Puvaneswari et al. 2006). Some researchers have investigated the dyeing mechanism of acid scarlet $3 \mathrm{R}$ dyes on Chinese fir but ignored that acid scarlet $3 \mathrm{R}$ is an azo dyestuff. It is a highly conjugated molecule containing a benzene ring, which has a greater impact on environmental water (Wang et al. 2018). This type of water (Class V) is mainly used for agricultural watering and general landscape watering. In recent years, the European Standards Committee has published the latest test standard for banned azo dyes as EN 14362-1 (2012), which proposed $30 \mathrm{mg} / \mathrm{kg}$ as the determination limit for banned azo colorants, and required that it should be "prohibited" rather than "restricted" (Ahlström et al. 2005). Therefore, in the process of synthesis and use, synthetic dyes will flow to animals and plants along the food chain, causing a series of problems in ecology and the environment during synthesis and use, forcing researchers to pay attention again and look for new dyestuffs.

The development and utilization of natural dyes have begun to receive attention again with the introduction of the concept of environmentally friendly dyes (Umbreen et al. 2008). Natural dyes contain natural pigments that are neither carcinogenic nor harmful to the environment. Their colors are soft, soothing, warm, and attractive. Natural dyes are earth-friendly and contribute to maintaining ecological balance (Moiz et al. 2010). Metal salts are able to combine with dyes to form dye aggregates, which make the fabric appear dark. Natural dyes made from Pterocarpus soyauxii was used to dye bamboo fiber fabrics, and the good dyeing effect and color fastness were obtained (Saha Tchinda et al. 2014). The color difference value of cotton fabric dyed with padouk and movingui natural dyes extract was found to be better than that of bamboo fiber and wood viscose fiber, which may be easier to combine with dye molecules due to lower crystallinity. Hematoxylin-dyed silk has certain antibacterial properties (Yang et al. 2018). The color difference value of wool fabric dyed with natural dyes from green tea was maintained at 10.50, and its color fastness was also good (Moiz et al. 2010). Some studies have shown that natural dyes have a certain relationship with the types of compounds (Zhang et al. 2018). Although some research on natural dyes has been carried out, little is known about the chromogenic components of natural dyes and how they bind to wood surfaces.

Pterocarpus macrocarpus Kurz is mainly produced in Myanmar, Laos, and Thailand. In Pingxiang City, Guangxi Province, P. macrocarpus is used as wood raw material to manufacture mahogany furniture. Nevertheless, a large quantity of shavings from this tree are produced during the processing of wood. Most of it is treated as waste, resulting in a large loss ( $\mathrm{Li}$ et al. 2016). P. macrocarpus contains a large number of inclusions, including phenolic compounds, terpenoids, and flavonoid pigments, so it is prepared as a natural dye for dyeing eucalyptus veneers.

The purpose of this study was to identify the key color-producing components in the $P$. macrocarpus dye to better explore the mechanisms of combination between dyes and eucalyptus veneers. This method not only addresses the environmental problems caused by incineration, but also enables its effective use. This research provides a 
theoretical basis for developing new natural dyes and increasing the value of eucalyptus in the future.

\section{EXPERIMENTAL}

\section{Materials}

Ten-year-old fast-growing Eucalyptus grandis $x$ urophylla was cut in Guangxi in the southwest of China. The sapwood was rotary cut and air-dried to make its moisture content (MC) less than $85 \%$. The crack-free, knotless wood veneers with smooth fibers and uniform color distribution were selected and prepared with dimensions of $30 \times 2.0 \times 30$ $\mathrm{mm}^{3}$ (Tangential $\times$ Radial $\times$ Longitudinal) .

\section{Preparation of Natural Dyes}

In 2018, Pterocarpus macrocarpus was harvested by researchers in Wacheng, Myanmar. The heartwood was processed into shavings. The shavings were washed with distilled water, and they were also air-dried to a MC less than $85 \%$. Afterwards, they were ground with a grinder. Wood powder of approximately 80 to 100 mesh was used as raw material and it was extracted using a Soxhlet apparatus with anhydrous ethanol. The ratio of wood powder mass to solvent mass is based on the preliminary experimental results of this research group. Related information and references are as follows (Yang et al. 2019). The concentration of the extraction solution was the same as the weight ratio of wood powder in an organic solvent $(0.05 \mathrm{~g} / \mathrm{mL})$, and the extraction temperature was the boiling point of anhydrous ethanol $\left(79^{\circ} \mathrm{C}\right) .12 .5$ grams of dye can be extracted per 100 grams of $P$. macrocarpus shavings. The solution was extracted completely when the liquid in the extraction tube was almost colorless. Subsequently, the extract was evaporated under the reduced pressure to obtain a concentrated solution, which was then freeze-dried under vacuum to obtain a dye. Finally, the dye was stored in a Petri dish in the refrigerator until it was used.

\section{Dyeing of Wood Veneers}

Because the volatility of absolute ethanol was reduced during the dyeing process, a specific condensation dyeing device (round bottom flask with condensing tube) from Leigu Co., Ltd. (Shanghai, China) was selected (Zhu et al. 2018). The dyeing process was completed by water bath heating. The factors, such as staining time, temperature, mass fraction of $\mathrm{NaCl}$ solution, and pigment, were investigated (Minitab Software, Minitab, LLC., Minitab, PA, USA). The factors and levels refer to previous experimental results (Sun et al. 2012). The factors and levels of the experimental setup are listed in Table 1.

Three pieces of eucalyptus veneers were vertically inserted into the groove of the dyeing apparatus and some appropriate space was left to ensure the evenness during the whole dyeing process. After being dyed, the eucalyptus veneer is placed in the shade for $48 \mathrm{~h}$ and dried naturally. The natural dyeing of eucalyptus veneers was ensured without adding mordant in the dyeing solution. The color difference of eucalyptus veneers before and after the dyeing process was tested. 
Table 1. Factors and Levels of Experimental Setup

\begin{tabular}{|c|c|c|c|c|}
\hline Level & Temp $\left({ }^{\circ} \mathrm{C}\right)$ & Dyeing Time $(\mathrm{h})$ & Mass Fraction of Pigment (\%) & Mass Fraction of $\mathrm{NaCl}(\%)$ \\
\hline 1 & 60 & 6 & 1.0 & 1.0 \\
\hline 2 & 70 & 8 & 2.0 & 1.5 \\
\hline 3 & 80 & 10 & 3.0 & 2.0 \\
\hline 4 & 90 & 12 & 4.0 & 2.5 \\
\hline
\end{tabular}

\section{Color Values Measurement}

The color change values of the samples dyed with dye solutions before and after dyeing were measured using colorimeter (ADCI series automatic colorimeter; Chentaike Co., Ltd., Beijing, China) under D65 illuminant and $10^{\circ}$ standard observer at three pieces of eucalyptus veneers, and the average data are reported. The eucalyptus veneers was recorded using the CIE- $L^{*}, a^{*}, b^{*}$ uniform color space (CIE-Lab) within a threedimensional color space, where $L^{*}$ indicates lightness, $a^{*}$ indicates hue on a green $(-)$ to red $(+)$ axis, and $b^{*}$ indicates hue on a blue $(-)$ to yellow $(+)$ axis $(\mathrm{Xu}$ et al. 2001). The values of each chromaticity parameter were collected, and the total color difference $(\Delta E)$, which denotes the surface color change, was calculated from Eqs. 1 to 4,

$$
\begin{aligned}
& \Delta L^{*}=L^{*}{ }_{\mathrm{a}}-L^{*} \mathrm{~b} \\
& \Delta a^{*}=a^{*}{ }_{\mathrm{a}}-a^{*}{ }_{\mathrm{b}} \\
& \Delta b^{*}=b^{*}{ }_{\mathrm{a}}-b^{*}{ }_{\mathrm{b}} \\
& \Delta E=\left[\left(\Delta L^{*}\right)^{2}+\left(\Delta a^{*}\right)^{2}+\left(\Delta b^{*}\right)^{2}\right]^{1 / 2}
\end{aligned}
$$

where the $\Delta L^{*}, \Delta a^{*}$, and $\Delta b^{*}$ represent the difference values of $L^{*}, a^{*}$, and $b^{*}$ of the wood veneers before $\left(L_{\mathrm{b}}{ }^{*}, a_{\mathrm{b}}{ }^{*}\right.$, and $\left.b_{\mathrm{b}}{ }^{*}\right)$ and after $\left(L_{\mathrm{a}}{ }^{*}, a_{\mathrm{a}}{ }^{*}\right.$, and $\left.b_{\mathrm{a}}{ }^{*}\right)$ dyeing, respectively (Zhu $e t$ al. 2018).

\section{Chemical Composition of the Extraction Analyses}

The chemical composition of dyestuff was analyzed using ultra-high performance liquid chromatography with quadrupole-electrostatic field Orbitrap high resolution-mass spectrometry (UPLC-Q-EXACTIVE-MS). The column was a $50 \mathrm{~mm} \times 2.1 \mathrm{~mm}, 1.7 \mu \mathrm{m}$ (inside diameter), ACQUITY UPLCBEHC18 column (Water Technologies Co., Ltd., Milford, USA). The mobile phases A and B consisted of $0.1 \%$ formic acid and $99.9 \%$ methanol, respectively. The elution gradient (26 min) was as follows. After maintaining the level of eluent B at 5\% for 2 min, it was linearly increased to $95 \%$ B within 18 min; then $95 \%$ B was maintained for 2 min. Finally, the gradient was switched to $5 \% \mathrm{~B}$ again over $4 \mathrm{~min}$, and the column was re-equilibrated for $3 \mathrm{~min}$. The flow rate of the mobile phase was kept at $0.3 \mathrm{~mL} / \mathrm{min}$, and the injection volume was set at $1 \mu \mathrm{L}$. The elution procedure was set according to the sample gradient shown in Table 2. The mass spectrometer method was performed in positive and negative mode in full scan MS mode with a mass range of 100 to $500 \mathrm{amu}$. The ion accumulation time was set to $30 \mathrm{~ms}$, with an event time of $300 \mathrm{~ms}$ with three repetitions. The triple-quadrupole mass spectrometer was an Agilent 1290 instrument that was equipped with an ESI source using jet stream technology (Agilent Technologies Co., Ltd., Santa Clara, CA, USA). The ion source parameters were set as follows: $300{ }^{\circ} \mathrm{C}$ of sheath gas temperature, $12 \mathrm{~L} / \mathrm{min}$ of sheath gas flow, $320{ }^{\circ} \mathrm{C}$ of gas temperature, $8 \mathrm{~L} / \mathrm{min}$ of gas flow, $30 \mathrm{psi}$ of nebulizer, $3000 \mathrm{~V}$ of capillary voltage, $0 \mathrm{~V}$ of nozzle voltage. 
Table 2. Gradient Elution Conditions of Mobile Phase for Samples

\begin{tabular}{|c|c|c|c|}
\hline $\begin{array}{c}\text { Injection Time } \\
(\mathrm{min})\end{array}$ & $\begin{array}{c}\text { Flow Velocity } \\
\left(\mathrm{mL} \cdot \mathrm{min}^{-1}\right)\end{array}$ & $\begin{array}{c}\text { Mobile Phase A } \\
(\%)\end{array}$ & $\begin{array}{c}\text { Mobile Phase B } \\
(\%)\end{array}$ \\
\hline 0 & 0.3 & 95 & 5 \\
\hline 2.0 & 0.3 & 95 & 5 \\
\hline 20.0 & 0.3 & 5 & 95 \\
\hline 22.0 & 0.3 & 5 & 95 \\
\hline 22.1 & 0.3 & 95 & 5 \\
\hline 26.0 & 0.3 & 95 & 5 \\
\hline
\end{tabular}

\section{FTIR and FESEM Analyses}

The surface chemical structure of eucalyptus veneers before and after dye was characterized using Fourier transform infrared spectroscopy (FTIR). All samples were mixed with $\mathrm{KBr}$ at a ratio of 1:100 and ground into ultrafine powder in the mortar. Then they were placed on the diamond crystal of the FTIR spectrometer (TENSOR II; Bruker, Karlsruhe, Germany). The spectra were collected in transmittance mode with 32 scans ranging from 400 to $4000 \mathrm{~cm}^{-1}$ at a resolution of $1 \mathrm{~cm}^{-1}$.

The samples were pasted on the sample table with a double-sided conductive adhesive and treated with gold spraying (Ion Sputter Coater 150; SuPro Instruments Co., Ltd., Shenzhen, China). The micromorphology of the eucalyptus veneers before and after dyeing was observed using a field emission scanning electron microscope (Hitachi s-3400n FESEM; Hitachi Ltd., Hitachi, Japan).

\section{Color Fastness to Washing}

The color difference value before and after washing of the dyed veneers was used as an index to measure the color fastness to washing (Ferguson and Taylor 2008). Each group of dyed veneers whose color had been measured was placed into a beaker with 100 $\mathrm{mL}$ of distilled water and heated in a constant temperature water bath at $60{ }^{\circ} \mathrm{C}$ for $2 \mathrm{~h}$. Then the wood chips were removed and air-dried at room temperature. After measuring the surface color, the color difference before and after the water washing treatment was calculated.

\section{RESULTS AND DISCUSSION}

\section{Main Chemical Composition of the Extraction Analysis}

Positive and negative ion chromatogram spectra of ethanol extraction are presented in Figs. 1 and 2. It can be clearly seen that main peaks were found at retention time between $7 \mathrm{~min}$ and $15 \mathrm{~min}$. For further clarification, relative peak areas were used to exhibit the relative content of main compositions of ethanol extraction, which can be obtained by calculating the ratio of each peak area.

The UPLC-Q-EXACTIVE Orbitrap-MS conditions were optimized to enable samples to obtain the best instrumental performance. Both positive and negative ion modes were employed to screen as many potential compounds in $P$. macrocarpus as possible, but the positive ion mode provided higher signal intensity and the ability to detect more peak signals, which may be due to the easy ionization of some compounds in the positive ion mode (Duan et al. 2017). 


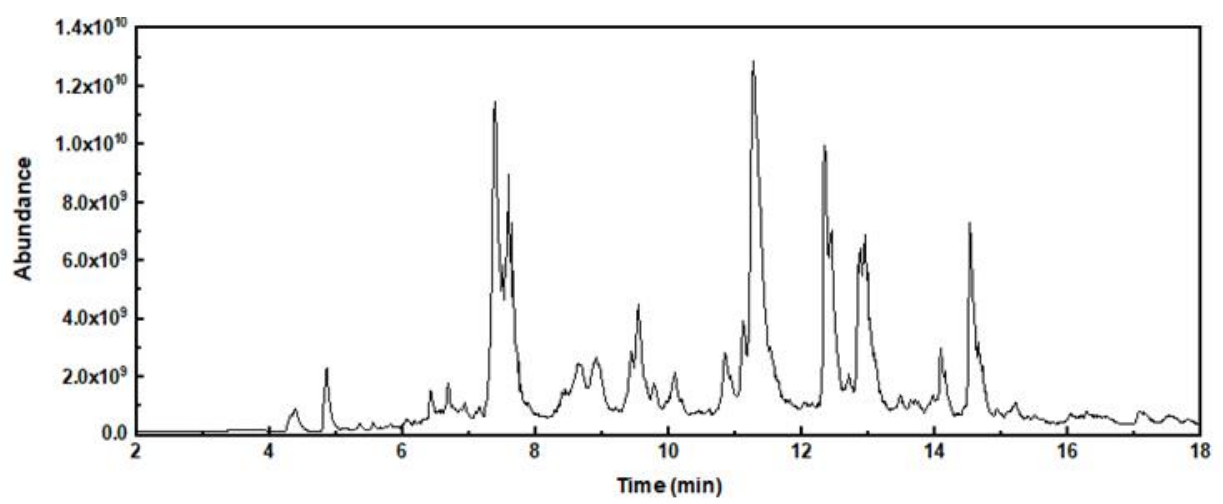

Fig. 1. Total ion chromatogram of mass spectrometer in positive ion mode

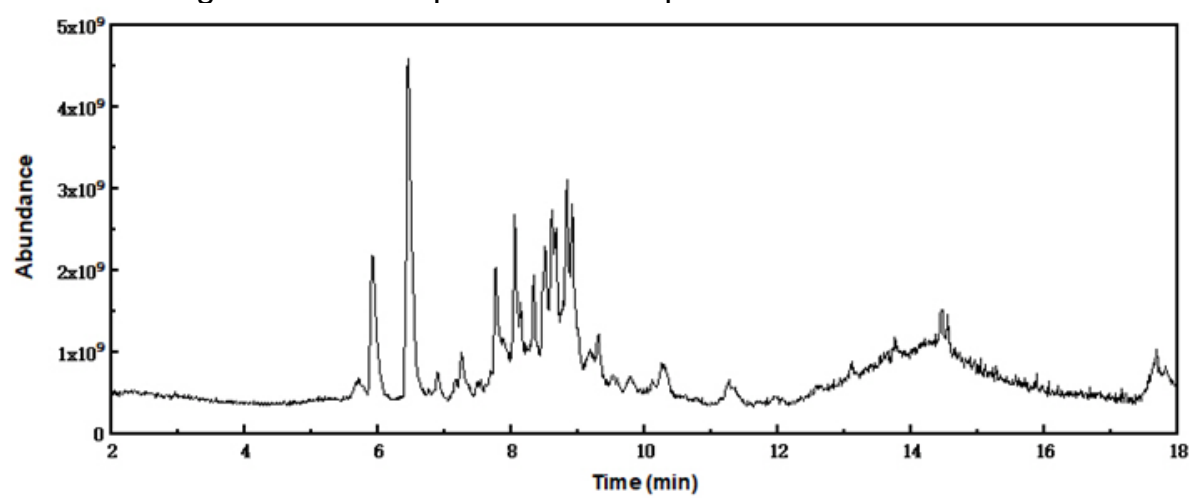

Fig. 2. Total ion chromatogram of mass spectrometer in negative ion mode

Table 3. Characterization of Chemical Constituents in Pigment from Pterocarpus macrocarpus Kurz Heartwood by UPLC-Q-Extractive Orbitrap-MS

\begin{tabular}{|c|c|c|c|c|c|c|c|}
\hline No. & $\begin{array}{l}\text { Reten- } \\
\text { tion } \\
\text { Time } \\
\text { (min) }\end{array}$ & Formula & $\begin{array}{l}\text { Experi- } \\
\text { mental } \\
\text { Molecular } \\
\text { Mass }\end{array}$ & $\begin{array}{c}\text { Theoretical } \\
\text { Molecular } \\
\text { Mass }\end{array}$ & $\begin{array}{l}\text { Ratios of } \\
\text { Fragment } \\
\text { lons }(\mathrm{m} / \mathrm{z})\end{array}$ & Component & Reference \\
\hline 1 & 4.677 & $\mathrm{C}_{21} \mathrm{H}_{20} \mathrm{O}_{11}$ & 448.10027 & $\begin{array}{c}{[\mathrm{M}+\mathrm{H}]^{+}} \\
448.10056\end{array}$ & $\begin{array}{r}431.096 \\
413.086 \\
396.075 \\
329.064 \\
311.054 \\
256.631\end{array}$ & Orientin & $\begin{array}{c}\text { Xu et al. } \\
\text { (2017) }\end{array}$ \\
\hline 2 & 5.045 & $\mathrm{C}_{21} \mathrm{H}_{20} \mathrm{O}_{10}$ & 432.10546 & $\begin{array}{c}{[\mathrm{M}+\mathrm{H}]^{+}} \\
432.10565\end{array}$ & $\begin{array}{c}415.101 \\
397.091 \\
379.080 \\
313.070 \\
269.080 \\
\end{array}$ & Vitexin & $\begin{array}{c}\text { Fu et al. } \\
\text { (2008) }\end{array}$ \\
\hline 3 & 5.097 & $\mathrm{C}_{16} \mathrm{H}_{12} \mathrm{O}_{6}$ & 300.06301 & $\begin{array}{c}{[\mathrm{M}+\mathrm{H}]^{+}} \\
300.06339\end{array}$ & $\begin{array}{l}269.043 \\
241.048 \\
213.054\end{array}$ & Diosmetin & $\begin{array}{c}\text { Sammani } \\
\text { et al. } \\
(2017)\end{array}$ \\
\hline 4 & 5.844 & $\mathrm{C}_{16} \mathrm{H}_{12} \mathrm{O}_{7}$ & 316.05815 & $\begin{array}{c}{[\mathrm{M}+\mathrm{H}]^{-}} \\
316.05830\end{array}$ & $\begin{array}{l}271.096 \\
253.085 \\
225.090 \\
179.033 \\
147.043\end{array}$ & Rhamnetin & $\begin{array}{l}\text { Marzouk et } \\
\text { al. (1999) }\end{array}$ \\
\hline
\end{tabular}




\begin{tabular}{|c|c|c|c|c|c|c|c|}
\hline 5 & 6.050 & $\mathrm{C}_{15} \mathrm{H}_{10} \mathrm{O}_{5}$ & 270.05263 & $\begin{array}{c}{[\mathrm{M}+\mathrm{H}]^{+}} \\
270.05282\end{array}$ & $\begin{array}{l}253.049 \\
183.080 \\
165.069 \\
137.059\end{array}$ & Genistein & $\begin{array}{l}\text { Tian et al. } \\
\text { (2011) }\end{array}$ \\
\hline 6 & 6.145 & $\mathrm{C}_{16} \mathrm{H}_{12} \mathrm{O}_{6}$ & 300.06301 & $\begin{array}{c}{[\mathrm{M}+\mathrm{H}]^{-}} \\
300.06339\end{array}$ & $\begin{array}{r}286.046, \\
269.044, \\
241.049, \\
213.054, \\
151.038 \\
137.023 \\
\end{array}$ & Hispidulin & $\begin{array}{l}\text { Ganzera et } \\
\text { al. (2005) }\end{array}$ \\
\hline 7 & 6.388 & $\mathrm{C}_{17} \mathrm{H}_{14} \mathrm{O}_{7}$ & 330.07353 & $\begin{array}{c}{[\mathrm{M}+\mathrm{H}]^{+}} \\
331.08176\end{array}$ & $\begin{array}{c}303.085 \\
271.059 \\
243.064 \\
215.070 \\
153.054 \\
107.049\end{array}$ & Malvidin & $\begin{array}{l}\text { Heier et al. } \\
\text { (2002) }\end{array}$ \\
\hline 8 & 6.400 & $\mathrm{C}_{14} \mathrm{H}_{12} \mathrm{O}_{3}$ & 228.07846 & $\begin{array}{c}{[\mathrm{M}+\mathrm{H}]^{+}} \\
228.07864\end{array}$ & $\begin{array}{l}211.075 \\
193.080 \\
135.043 \\
119.043\end{array}$ & Resveratrol & $\begin{array}{l}\text { Wang et al. } \\
\text { (2002) }\end{array}$ \\
\hline 9 & 6.463 & $\mathrm{C}_{21} \mathrm{H}_{20} \mathrm{O}_{10}$ & 254.05769 & $\begin{array}{c}{[\mathrm{M}+\mathrm{H}]^{+}} \\
254.05791\end{array}$ & $\begin{array}{r}217.185, \\
189.163, \\
147.043, \\
123.044, \\
107.049 \\
\end{array}$ & Chrysin & $\begin{array}{l}\text { Chen et al. } \\
\quad(2010)\end{array}$ \\
\hline 10 & 6.641 & $\mathrm{C}_{15} \mathrm{H}_{12} \mathrm{O}_{4}$ & 256.07326 & $\begin{array}{c}{[\mathrm{M}+\mathrm{H}]^{+}} \\
256.07356\end{array}$ & $\begin{array}{c}239.069, \\
211.074, \\
148.047\end{array}$ & $\begin{array}{c}4^{\prime}, 7- \\
\text { Dihydroxyflav } \\
\text { anone }\end{array}$ & $\begin{array}{c}\text { Chae et al. } \\
\quad(2016)\end{array}$ \\
\hline 11 & 6.857 & $\mathrm{C}_{15} \mathrm{H}_{10} \mathrm{O}_{5}$ & 270.05263 & $\begin{array}{c}{[\mathrm{M}+\mathrm{H}]^{+}} \\
270.05282\end{array}$ & $\begin{array}{c}243.065 \\
183.080 \\
147.043 \\
119.049\end{array}$ & Apigenin & $\begin{array}{l}\text { Abdullah et } \\
\text { al. (2017) }\end{array}$ \\
\hline 12 & 6.869 & $\mathrm{C}_{16} \mathrm{H}_{12} \mathrm{O}_{5}$ & 284.06831 & $\begin{array}{c}{[\mathrm{M}-\mathrm{H}]^{-}} \\
284.06847\end{array}$ & $\begin{array}{r}253.049 \\
225.054 \\
177.054 \\
153.054 \\
137.023 \\
123.044 \\
\end{array}$ & Glycitein & $\begin{array}{l}\text { Romani et } \\
\text { al. (2010) }\end{array}$ \\
\hline 13 & 7.282 & $\mathrm{C}_{15} \mathrm{H}_{22} \mathrm{O}$ & 218.16675 & $\begin{array}{c}{[\mathrm{M}-\mathrm{H}]^{-}} \\
218.16707\end{array}$ & $\begin{array}{l}\text { 201.163, } \\
\text { 159.116, } \\
135.116 \\
107.085\end{array}$ & Nootkatone & $\begin{array}{l}\text { Xie et al. } \\
\text { (2009) }\end{array}$ \\
\hline 14 & 8.865 & $\mathrm{C}_{16} \mathrm{H}_{12} \mathrm{O}_{4}$ & 228.0784 & $\begin{array}{c}{[\mathrm{M}+\mathrm{H}]^{+}+228.07} \\
864\end{array}$ & $\begin{array}{r}237.053, \\
213.089, \\
197.059, \\
118.041 \\
82.136\end{array}$ & Formononetin & $\begin{array}{l}\text { Xie et al. } \\
\text { (2014) }\end{array}$ \\
\hline 15 & 9.236 & $\mathrm{C}_{16} \mathrm{H}_{12} \mathrm{O}_{5}$ & 284.06832 & $\begin{array}{c}{[\mathrm{M}+\mathrm{H}]^{+} 284.06} \\
847\end{array}$ & $\begin{array}{c}257.080 \\
175.038 \\
151.038 \\
123.044\end{array}$ & (-)-Maackiain & $\begin{array}{c}\text { Gao et al. } \\
\text { (2011) }\end{array}$ \\
\hline 16 & 12.322 & $\mathrm{C}_{9} \mathrm{H}_{6} \mathrm{O}_{3}$ & 162.03147 & $\begin{array}{c}{[\mathrm{M}+\mathrm{H}]^{+}+162.03} \\
169\end{array}$ & $\begin{array}{r}135.044 \\
79.054\end{array}$ & $\begin{array}{l}\text { 4-Hydroxy- } \\
\text { coumarin }\end{array}$ & $\begin{array}{l}\text { Jung and } \\
\text { Park (2009) }\end{array}$ \\
\hline
\end{tabular}




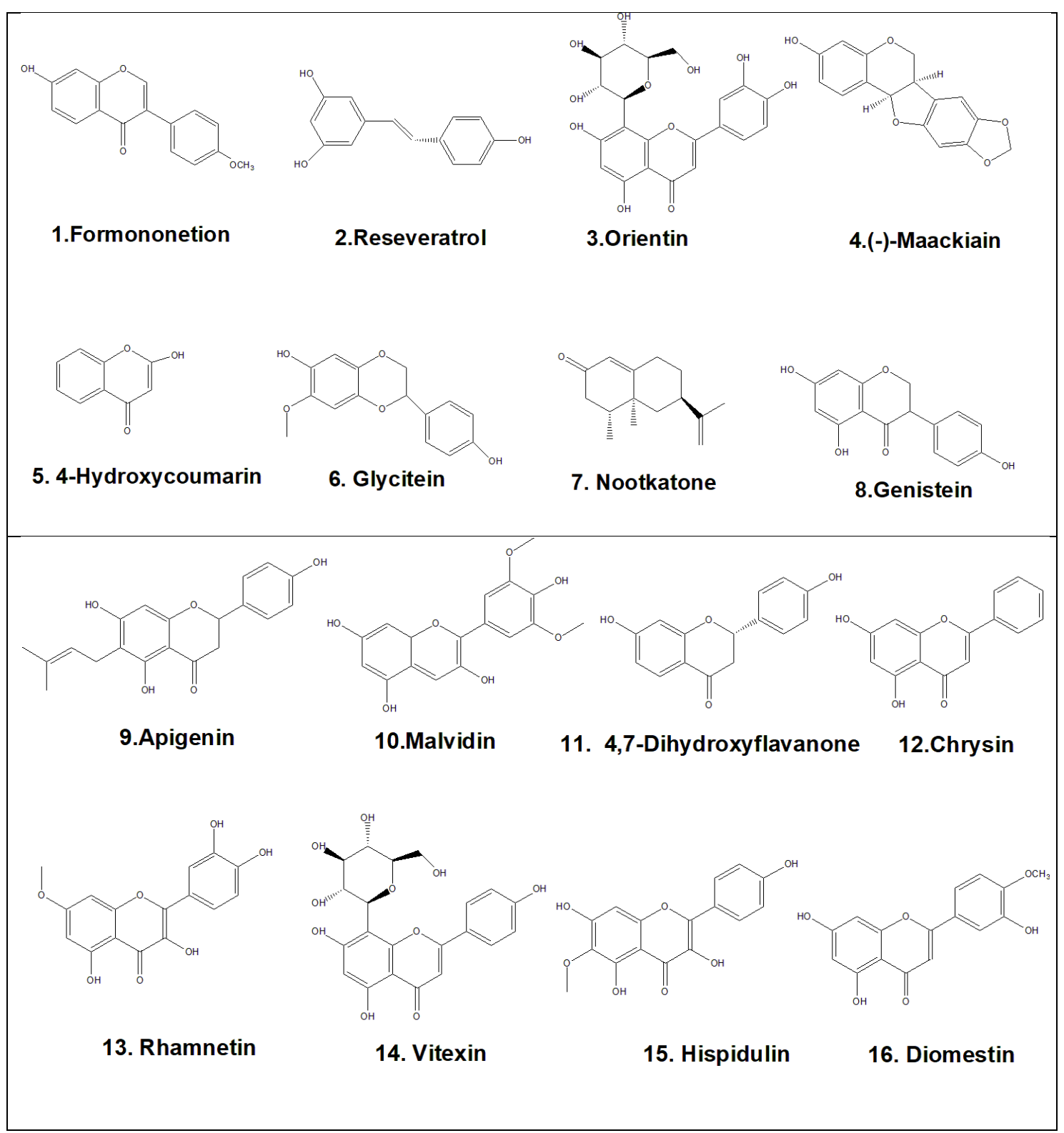

Fig. 3. The molecular structure of each compound

Among them, 16 compounds were tentatively identified by comparison with (thermo state) reference standards. After that, the compounds were analyzed and determined based on the accurate mass of quasimolecular, fragmentation ions, and MS spectra with the literature. The chemical compositions were identified by retrieval of mass spectral and Wiley libraries.

As shown in Table 3, there were 16 main chemical components. These 16 compounds were formononeti, resveratrol, orientin, (-)-maackiain, 4-hydroxycoumarin, glycitein, nootkatone, genistein, apigenin, malvidin, 4',7-dihydroxyflavanone, chrysin, rhamnetin, vitexin, hispidulin, and diosmetin.

The results presented in Figs. 3 and 4 indicated that the extracts of $P$. macrocarpus contained flavonoids and phenols compounds. Flavone has chromofunctional groups, such as conjugated carbonyl, non-conjugated carbonyl, hydroxyl, and carbon-carbon triple bonds, which probably led to the surface discoloration of wood veneers after dyeing. 
However, the relationship between flavonoid and the specific chromaticity index $\left(L, a^{*}\right.$, and $\left.b^{*}\right)$ variation needs further study.

\section{Influence of Main Factors on Dyeing Effect}

The eucalyptus veneers were dyed according to the orthogonal design table, and the color difference before and after dyeing was measured (Table 4). The order of the factors affecting the staining was: dye mass fraction $>$ temperature $>$ dyeing time $>\mathrm{NaCl}$ mass fraction. The analysis of variance showed that dye mass fraction and temperature had significant effects on the test results $(\mathrm{P}<0.05)$.

Table 4. Comparison Results of Color Differences Before and After Dyeing

\begin{tabular}{|c|c|c|c|c|c|c|}
\hline No. & $\begin{array}{c}\text { Dyeing } \\
\text { Temperature } \\
\left({ }^{\circ} \mathrm{C}\right)\end{array}$ & $\begin{array}{c}\text { Dyeing } \\
\text { Time } \\
(\mathrm{h})\end{array}$ & $\begin{array}{c}\text { Dye } \\
\text { Mass } \\
\text { Fraction } \\
(\%)\end{array}$ & $\begin{array}{c}\text { NaCl } \\
\text { Mass } \\
\text { Fraction } \\
(\%)\end{array}$ & $\begin{array}{c}\text { Null } \\
\text { Columns }\end{array}$ & $\begin{array}{c}\text { Color Difference } \\
\text { Before and After } \\
\text { Dyeing }\end{array}$ \\
\hline 1 & 60 & 6 & 1 & 1.0 & 1 & 17.92 \\
\hline 2 & 60 & 8 & 2 & 1.5 & 2 & 30.34 \\
\hline 3 & 60 & 10 & 3 & 2.0 & 3 & 39.66 \\
\hline 4 & 60 & 12 & 4 & 2.5 & 4 & 36.06 \\
\hline 5 & 70 & 6 & 2 & 2.0 & 4 & 34.82 \\
\hline 6 & 70 & 8 & 1 & 2.5 & 3 & 19.72 \\
\hline 7 & 70 & 10 & 4 & 1.0 & 2 & 42.79 \\
\hline 8 & 70 & 12 & 3 & 1.5 & 1 & 36.06 \\
\hline 9 & 80 & 6 & 3 & 2.5 & 2 & 36.22 \\
\hline 10 & 80 & 8 & 4 & 2.0 & 1 & 41.56 \\
\hline 11 & 80 & 10 & 1 & 1.5 & 4 & 30.23 \\
\hline 12 & 80 & 12 & 2 & 1.0 & 3 & 33.35 \\
\hline 13 & 90 & 6 & 4 & 1.5 & 3 & 43.32 \\
\hline 14 & 90 & 8 & 3 & 1.0 & 4 & 47.13 \\
\hline 15 & 90 & 10 & 2 & 2.5 & 1 & 43.87 \\
\hline 16 & 90 & 12 & 1 & 2.0 & 2 & 41.60 \\
\hline Average 1 $\left(k_{1}\right)$ & 31.00 & 33.07 & 27.37 & 35.30 & & \\
\hline Average 2 $\left(k_{2}\right)$ & 33.35 & 34.69 & 35.59 & 34.99 & & \\
\hline Average 3 $\left(k_{3}\right)$ & 35.34 & 39.14 & 39.77 & 39.41 & & \\
\hline Average 4 $\left(k_{4}\right)$ & 43.98 & 36.77 & 40.93 & 33.97 & & \\
\hline Range $(R)$ & 12.98 & 6.07 & 13.56 & 5.44 & & \\
\hline & & & & & & \\
\hline
\end{tabular}

The best process parameters were selected from a higher level of factors. They were $90{ }^{\circ} \mathrm{C}$ of dyeing temperature, $10 \mathrm{~h}$ of dyeing time, $4 \mathrm{wt} \%$ of dyeing liquid, and $1.5 \mathrm{wt} \%$ $\mathrm{NaCl}$. In Fig. 4, the dyed samples were compared with the real picture of $P$. macrocarpus. The color difference value was calculated as 40.02. The color difference values of samples 3, 7, and 10 were slightly different from those of $P$. macrocarpus. After observation and comparison (Fig. 4), No. 10 was the closest to P. macrocarpus in color. 
Table 5. Analyses of Variance

\begin{tabular}{|c|c|c|c|c|c|}
\hline Factor & $\begin{array}{l}\text { Sum of } \\
\text { Squares }\end{array}$ & Freedom & $\mathrm{F}$ & $\mathrm{P}$ & $\begin{array}{l}\text { Significant } \\
\text { Figure }\end{array}$ \\
\hline Temperature & 384.69 & 3 & 10.25 & 0.044 & $\begin{array}{c}\text { Significance } \\
P<0.05\end{array}$ \\
\hline Time & 82.85 & 3 & 2.21 & 0.266 & \\
\hline $\begin{array}{c}\text { Dye Mass } \\
\text { Fraction (\%) }\end{array}$ & 452.72 & 3 & 12.06 & 0.035 & $\begin{array}{c}\text { Significance } \\
\mathrm{P}<0.05\end{array}$ \\
\hline $\begin{array}{c}\mathrm{NaCl} \text { Mass } \\
\text { Fraction (\%) }\end{array}$ & 69.00 & 3 & 1.84 & 0.315 & \\
\hline Error & 37.52 & 3 & & & \\
\hline
\end{tabular}
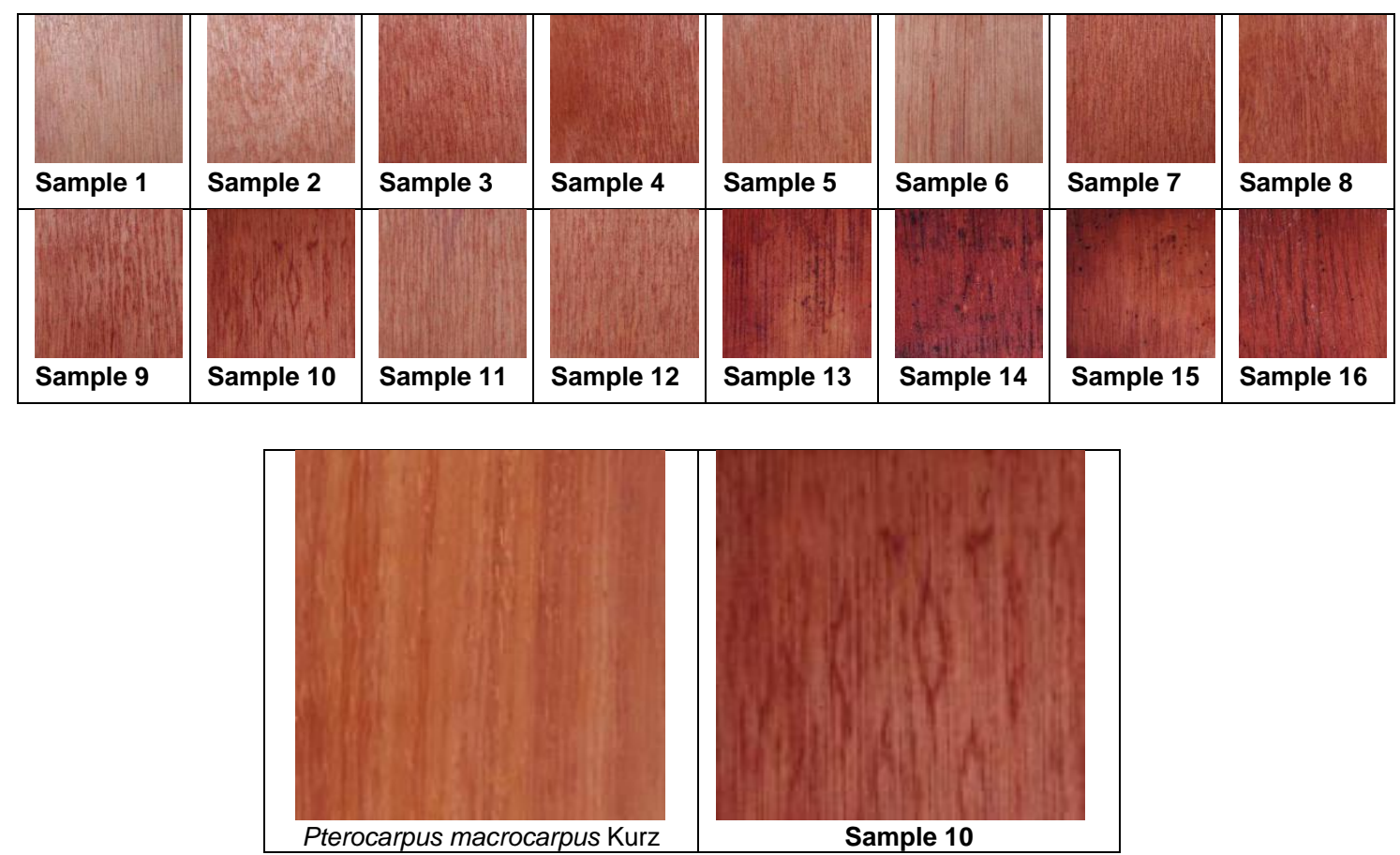

Fig. 4. Dyeing effect figures of test samples (samples 1 to 16) and comparison of sample 13 and Pterocarpus macrocarpus Kurz

\section{Effect of Process Parameters on the Dyeing Effect of Eucalyptus Veneer}

Influence of temperature on dyeing effect

As shown in Fig. 5a, temperature had a greater effect on the dyeing effect of eucalyptus veneer than dyeing time. With increasing the temperature, the color difference of eucalyptus veneers gradually increased. The color difference value increased from 31.0 to 44.0. According to the diffusion principle, the higher the temperature, the larger the diffusion coefficient, indicating that the molecular diffusion speed becomes faster (Morita et al. 1986). Therefore, the dyeing solution of flavonoids and phenolic compounds diffused faster in the wood ducts and pits, and the color of the specimen became darker. When the 
temperature rose up to $90{ }^{\circ} \mathrm{C}$, the color difference of the veneers reached the highest value, that is, the darkest color. The optimum dyeing temperature was $90{ }^{\circ} \mathrm{C}$.

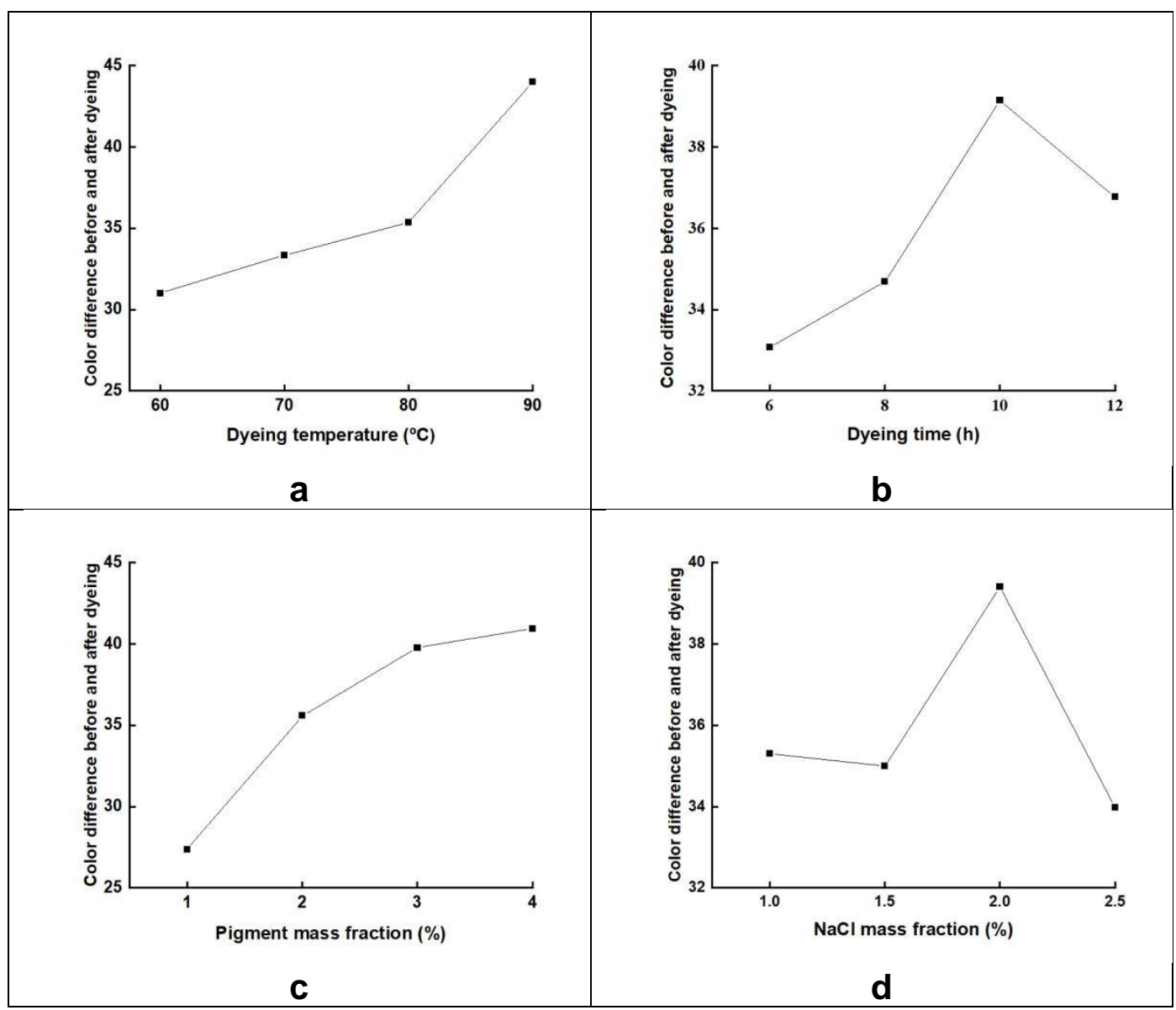

Fig. 5. Staining effect curve of different influencing factors

\section{Effect of dyeing time on dyeing effect}

As shown in Fig. 5b, the color difference value of eucalyptus veneers was almost unchanged when the dyeing time was 6 to $8 \mathrm{~h}$, and it increased after $8 \mathrm{~h}$. With the extension of the dyeing time, the pigment in the dye gradually penetrated the internal structure of the specimen, but the combination still needed a long time. The color difference of eucalyptus veneers reached the maximum at $10 \mathrm{~h}$, which was determined as the best dyeing time.

\section{Effect of mass fraction of dyeing solution on dyeing effect}

As shown in Fig. 5c, the color difference of eucalyptus veneers increased with increased mass fraction of dyeing solution. With increased mass fraction, the contact areas between pigment of dyeing solution and the wood fibers increased, which helped the wood to absorb the dye liquor and improved the dyeing effect. The best mass fraction of dyeing solution was $4 \%$.

Effect of mass fraction of $\mathrm{NaCl}$ solution on dyeing effect

As shown in Fig. 5d, the color difference of eucalyptus veneers increases with the mass fraction of $\mathrm{NaCl}$ added. The specimen color became deeper. In the process of wood 
dyeing, $\mathrm{NaCl}$ can provide significantly positively charged sodium ions (Burkinshaw and Salihu 2017), which can reduce the negative charge repulsion between the surface of the wood fibers and the flavonoids and phenolic compounds in dyes. This method can effectively reduce the inhibition effect of dye on the surface of wood fibers, allowing the dye molecules to approach closer to them during treatment with aqueous solution to improve the dyeing rate. The best mass fraction of $\mathrm{NaCl}$ solution was $2.0 \%$.

\section{Color Fastness Test}

Table 6 shows the color difference results of stained eucalyptus veneers before and after washing.

Table 6. Comparison Results of Color Differences Before and After Washing

\begin{tabular}{|c|c|c|c|c|c|}
\hline No. & $\begin{array}{c}\text { Dyeing } \\
\text { Temperature } \\
\left({ }^{\circ} \mathrm{C}\right)\end{array}$ & $\begin{array}{l}\text { Dyeing } \\
\text { Time } \\
\text { (h) }\end{array}$ & $\begin{array}{c}\text { Dye Mass } \\
\text { Fraction } \\
(\%)\end{array}$ & $\begin{array}{c}\text { NaCl Mass } \\
\text { Fraction } \\
\text { (\%) }\end{array}$ & $\begin{array}{l}\text { Color Difference Before } \\
\text { and After Washing }\end{array}$ \\
\hline 1 & 60 & 8 & 1 & 1.0 & 1.04 \\
\hline 2 & 60 & 10 & 2 & 1.5 & 5.50 \\
\hline 3 & 60 & 12 & 3 & 2.0 & 7.99 \\
\hline 4 & 60 & 14 & 4 & 2.5 & 0.59 \\
\hline 5 & 70 & 8 & 2 & 2.0 & 5.20 \\
\hline 6 & 70 & 10 & 1 & 2.5 & 5.62 \\
\hline 7 & 70 & 12 & 4 & 1.0 & 3.52 \\
\hline 8 & 70 & 14 & 3 & 1.5 & 2.88 \\
\hline 9 & 80 & 8 & 3 & 2.5 & 2.34 \\
\hline 10 & 80 & 10 & 4 & 2.0 & 4.52 \\
\hline 11 & 80 & 12 & 1 & 1.5 & 3.53 \\
\hline 12 & 80 & 14 & 2 & 1.0 & 3.66 \\
\hline 13 & 90 & 8 & 4 & 1.5 & 4.16 \\
\hline 14 & 90 & 10 & 3 & 1.0 & 3.47 \\
\hline 15 & 90 & 12 & 2 & 2.5 & 3.24 \\
\hline 16 & 90 & 14 & 1 & 2.0 & 3.11 \\
\hline Average $1\left(k_{1}\right)$ & 3.780 & 3.185 & 3.325 & 2.923 & \\
\hline Average $2\left(k_{2}\right)$ & 4.305 & 4.777 & 4.400 & 4.018 & \\
\hline Average $3\left(k_{3}\right)$ & 3.512 & 4.570 & 4.170 & 5.205 & \\
\hline Average $4\left(k_{4}\right)$ & 3.495 & 2.560 & 3.197 & 2.948 & \\
\hline Range $(R)$ & 0.810 & 2.217 & 1.203 & 2.282 & \\
\hline
\end{tabular}

The relatively small variation in the color difference value indicated better color fastness (Zhao et al. 2014). In this test, the average color difference of the stained veneers before and after washing was 3.77. This small value of the color difference indicated that the color fastness of the stained veneers was relatively good. The order of the factors affecting the color fastness was as follows: $\mathrm{NaCl}$ mass fraction $>$ dyeing time $>$ dye mass fraction $>$ temperature. The optimal combination of process parameters based on the highest color fastness to washing was: $70{ }^{\circ} \mathrm{C}$ of dyeing temperature, $8 \mathrm{~h}$ of dyeing time, 2 $\mathrm{wt} \%$ of dyeing solution, and $2 \mathrm{wt} \%$ of $\mathrm{NaCl}$ solution.

The flavonoids in the P. macrocarpus dye and wood fibers were mainly combined by intermolecular hydrogen bonding and adsorption (Clerck et al. 2007). During the combination process, $\mathrm{NaCl}$ can reduce the negative charge on the surface of the Eucalyptus 
veneers to reduce the repulsive force of the negative charge to the dye anions and improve the binding force (Burkinshaw and Salihu 2017). Therefore, the main factor affecting the color fastness of eucalyptus veneers was the $\mathrm{NaCl}$ mass fraction. Table 6 lists the various factors affecting the chromaticity value.

\section{FTIR Analysis of the Untreated and Samples Dyed with Absolute Ethanol Extraction}

Figure 6 presents the FTIR spectra of the samples before and after dyeing with ethanol extraction. The main peaks at $3330 \mathrm{~cm}^{-1}$ and $2928 \mathrm{~cm}^{-1}$ were ascribed to hydroxyl groups and $\mathrm{C}-\mathrm{H}$ stretching vibration, respectively (Devashankar 2017). In addition, the peaks at $1736 \mathrm{~cm}^{-1}$ corresponded to the cellulose, hemicellulose, and lignin in wood (Wang et al. 2016).

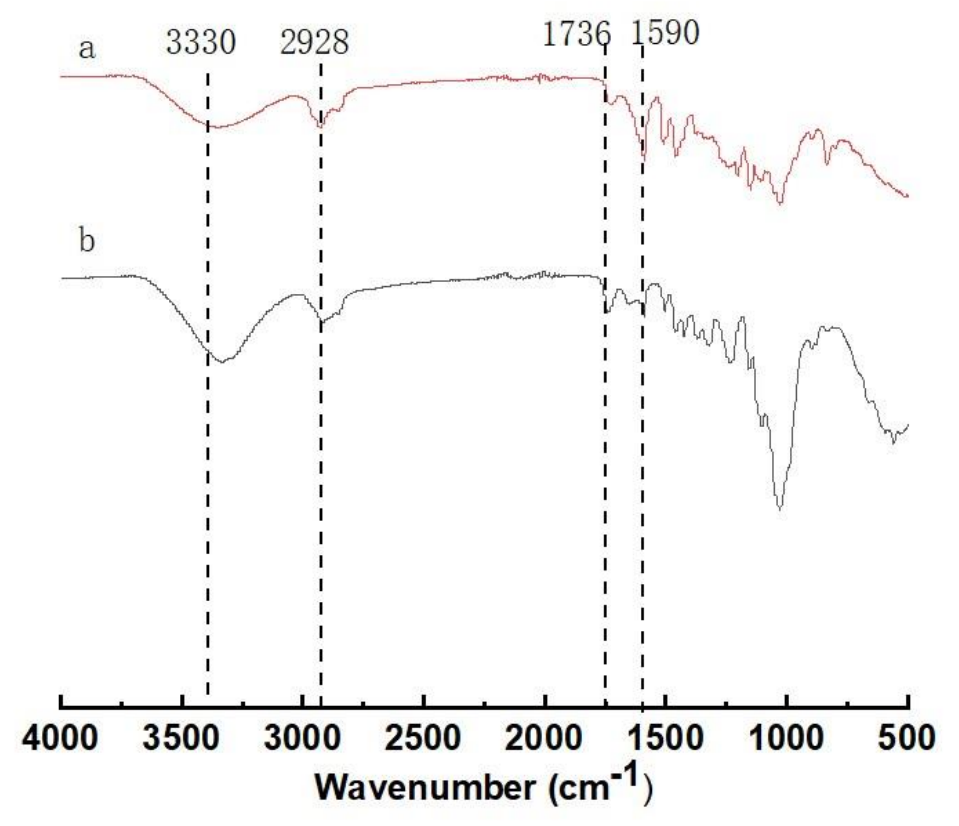

Fig. 6. FTIR spectra of untreated (b) and dyed eucalyptus wood (a)

After dyeing the Eucalyptus veneers, the intensity of characteristic peaks at 3330 $\mathrm{cm}^{-1}$ and $2928 \mathrm{~cm}^{-1}$ increased with the addition of the dye solution. This may be because the flavonoids in the dye solution were adsorbed on the wood surface. The compounds contain hydroxyl groups, which increased the amount of hydroxyl groups on the wood surface, resulting in an increase in the intensity of the $(-\mathrm{OH})$ characteristic peak.

In contrast, the dyed sample had a carbonyl $\mathrm{C}=\mathrm{O}$ stretch vibration peak located at $1590 \mathrm{~cm}^{-1}$, which is attributed to the fact that flavonoids in the dye are adsorbed to the wood surface by intermolecular hydrogen bonding during the preparation of the dyed sample (Huang et al. 2014).

It can be seen that the intensity of the peaks located between $1721 \mathrm{~cm}^{-1}$ and 1615 $\mathrm{cm}^{-1}$ became stronger, indicating that the flavonoids were well adsorbed on the wood surface. These results demonstrated that only physical adsorption occurred between the natural dyestuff and wood tissues (Wang et al. 2017). 


\section{FESEM Analysis}

In the transverse section of the untreated sample, circular tube holes were observed to be aligned neatly with axial parenchyma cells at magnification (Fig. 7A). The surface of wood fiber and the vessel wall of the untreated sample were smooth (Fig. 7B); the pits on the vessel wall (Fig. 7C) and xylem ray cells (Fig. 7D) were clearly visible. After the dyeing process, as shown in Fig. 7E, it was observed that the dyeing solution partially covered the duct in the cross-section of the wood, and the axial thin-walled tissue was completely covered with good flatness (Fig. 7F). In the tangential section of the dyed sample, both the wood ray (Fig. 7G) and the vessel wall (Fig. 7H) were covered by the dyestuff. Moreover, some pits were even completely covered (Fig. $7 \mathrm{H})$. The results indicated that the flavonoids and phenolic compounds in the dyes formed physical adsorption with wood fibers, which can be stabilized on the wood surface (Peters et al. 2008; Guimaraes et al. 2011).

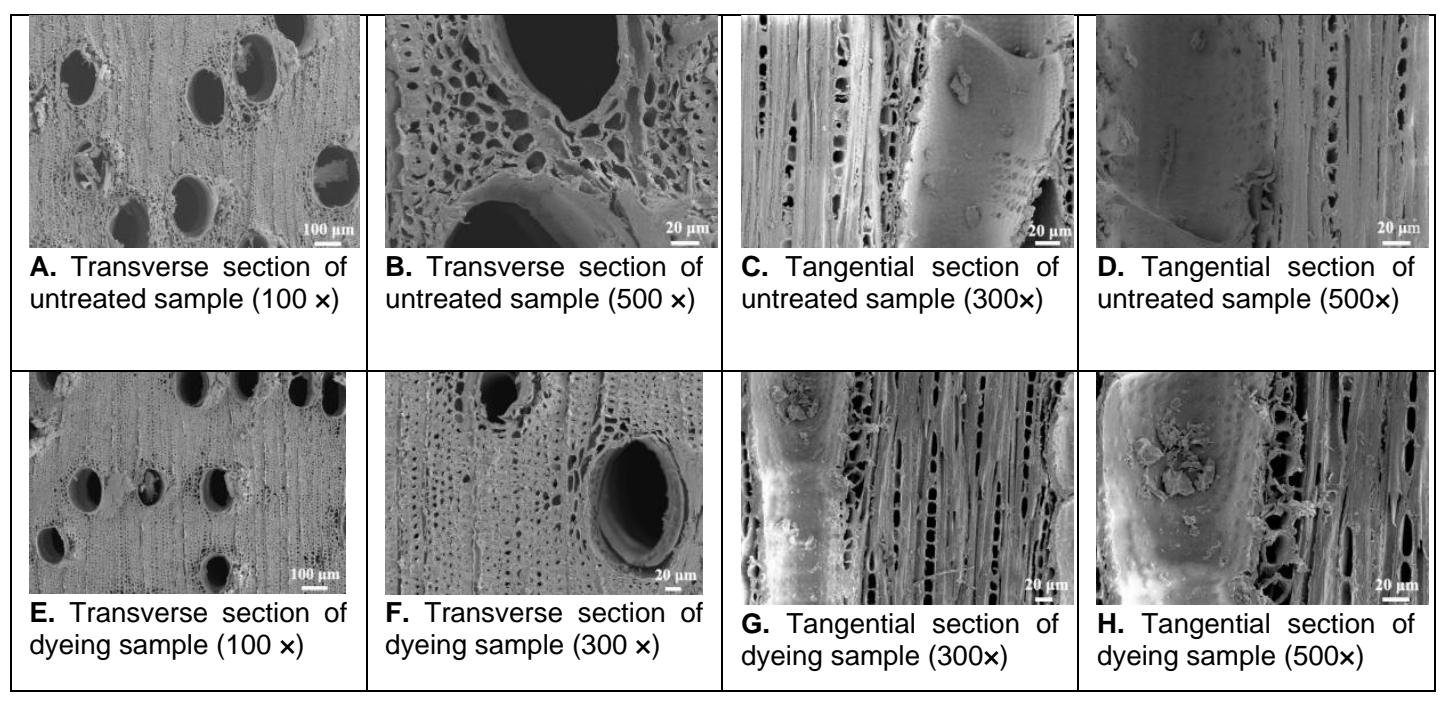

Fig. 7. FESEM micrographs of untreated and dyed eucalyptus wood

After the dyeing mechanism is determined, the next study can explore which components of the dye are more likely to bind to the wood surface. By changing the functional groups on the wood surface, the dye can be more firmly bound to the wood surface. In addition, it can show different colors because the dye contains different chromophoric groups and auxochromic groups. When the composition of the heartwood dyestuff from Pterocarpus macrocarpus Kurz is ascertained, these functional groups can be modified to change the color. In this way, the dye can change from a single color to multiple colors, thereby exploiting the color system of natural products. It can lay a theoretical foundation for improving the color fastness of eucalyptus stained wood and developing more colors.

\section{CONCLUSIONS}

1. The UPLC-Q-EXACTIVE-MS method was used to isolate and identify 16 kinds of flavonoids and phenolic compounds from the heartwood pigments of Pterocarpus macrocarpus Kurz. 
2. The pigment was extracted from the heartwood of Pterocarpus macrocarpus Kurz to make a natural dye, and then the eucalyptus veneers were dyed. The order of factors influencing the dyeing effect was as follows: temperature > mass fraction of dyeing solution $>$ dyeing time $>$ mass fraction of $\mathrm{NaCl}$ solution. Through the analysis of variance of orthogonal test, the optimal dyeing process parameters were obtained as follows: $90{ }^{\circ} \mathrm{C}$ of temperature, $4 \mathrm{wt} \%$ of dyeing solution, $2 \mathrm{wt} \% \mathrm{NaCl}$ solution, and 12 $\mathrm{h}$ of dyeing time. In addition, the color fastness of washed samples was measured, and the order of factors was as follows: mass fraction of $\mathrm{NaCl}>$ dyeing time $>$ mass fraction of dyeing solution > temperature. The main factor affecting the color fastness of the dyed sample was temperature. The optimal dyeing process for washing with water was that the temperature was $90^{\circ} \mathrm{C}$, the dyeing time was $10 \mathrm{~h}$, the mass fraction of pigment was $4 \%$, and the mass fraction of $\mathrm{NaCl}$ solution was $2.0 \%$.

3. The dyeing mechanisms were obtained by detecting the pigment composition of the heartwood of Pterocarpus macrocarpus Kurz combined with infrared and electron microscopy analysis. The natural dye was stably bound to the tracheid, axial tracheid wall, and wood-ray parenchyma cells, as well as the axial thin-walled tissue and chordal section of wood through physical adsorption and intermolecular hydrogen bonding.

\section{ACKNOWLEDGMENTS}

This research was funded by the "Guangxi Innovation-Driven Development Fund in China" (No. AA17204087-14) and the State Forestry Administration Zhongnan Key Laboratory of Fast-growing Breeding Project Fund Project in China (KF2018-02).

\section{REFERENCES CITED}

Abdullah, F. I., Chua, L. S., and Rahmat, Z. (2017). "Prediction of c-glycosylated apigenin (vitexin) biosynthesis in Ficus deltoidea based on plant proteins identified by LC-MS/MS," Frontiers in Biology 12(6), 448-458. DOI: 10.1007/s11515-0171472-0

Ahlström, L. H., Eskilsson, C. S., and Björklund, E. (2005). "Determination of banned azo dyes in consumer goods," Trends in Analytical Chemistry 24(1), 49-56. DOI: 10.1016/j.trac.2004.09.004

Burkinshaw, S. M., and Salihu, G. (2017). "The role of auxiliaries in the immersion dyeing of textile fibres: Part 9 practical aspects of the role of inorganic electrolytes in dyeing cellulosic fibres with pure reactive dyes," Dyes and Pigments 161, 628-641. DOI: $10.1016 /$ j.dyepig.2017.10.014

Cao, L., Xie, M. H., and Zhao, G. J. (2003). "Characteristics and uses of imported wood (5)," Forest Products Industry 30(6), 50-51. DOI: 10.1002/(SICI)10974628(20000725)77:43.0.CO;2-4

Chae, H. S., Yoo, H., Kim, Y. M., Choi, Y. H., Lee, C. H., and Chin, Y. W. (2016). "Anti-inflammatory effects of 6,8-diprenyl-7,4'-dihydroxyflavanone from Sophora tonkinensis on lipopolysaccharide-stimulated raw 264.7 cells," Molecules 21(10), Article number 1413. DOI: 10.3390/molecules21101413 
Chen, X. L., Li, X. Y., Yuan, J. W., Qu, Z. B., Jiang, Y. Q., and Qu, L. B. (2010). "Synthesis of new types of n-arylpiperazine phosphoramide analogues of chrysin," Journal of the Chinese Chemical Society 57, 144-148. DOI: 10.1002/jccs.201000022

Clerck, K. D., Rahier, H., Mele, B. V., Westbroek, P., and Kiekens, P. (2007). "Dyefiber interactions in pet fibers: Hydrogen bonding studied by IR-spectroscopy," Journal of Applied Polymer Science 106(3), 1648-1658. DOI: 10.1002/app.26714

Devashankar, S. (2017). "FTIR, powder X-RD and DSC analysis of African Padauk wood to elucidate possible applications," Macromolecular Symposia 376(1), Article ID 1700012. DOI: 10.1002/masy.201700012

Duan, S., Qi, W., Zhang, S., Huang, K., and Yuan, D. (2017). "Ultra high performance liquid chromatography coupled with electrospray ionization/quadrupole time-of-flight mass spectrometry for the rapid analysis of constituents in the traditional Chinese medicine formula Wu-Ji-Bai-Feng-Pill," Journal of Separation Science 40(20), 39773986. DOI: $10.1002 /$ jssc. 201700438

EN 14362-1 (2012). "Methods for determination of certain aromatic amines derived from azo colorants - Part 1: Detection of the use of certain azo colorants accessible with and without extracting the fibres," European Committee for Standardization, Belgium, Brussels.

Ferguson, A. D., and Taylor, T. P. (2008). "Anon standard methods for the determination of the color fastness of textiles and leather," Coloration Technology 96(1), 18-18. DOI: 10.1111/j.1478-4408.1980.tb03495.x

Fu, Y., Zu, Y., Liu, W., Zhang, L., Tong, M., and Efferth, T. (2008). "Determination of vitexin and isovitexin in pigeonpea using ultrasonic extraction followed by LC-MS," Journal of Separation Science 31(2), 268-275. DOI: 10.1002/jssc.200700312

Ganzera, M., Pöcher, A., and Stuppner, H. (2005). "Differentiation of Cirsium japonicum and C. setosum by TLC and HPLC-MS," Phytochemical Analysis 16(3), 205-209. DOI: $10.1002 /$ pca.846

Gao, S., Yang, Z., Yin, T., You, M., and Hu, M. (2011). "Validated LC-MS/MS method for the determination of maackiain and its sulfate and glucuronide in blood: Application to pharmacokinetic and disposition studies," Journal of Pharmaceutical and Biomedical Analysis 55(2), 288-293. DOI: 10.1016/j.jpba.2011.01.015

GB 3838-2002 (2002). "Environmental quality standards for surface water," Standardization Administration of China, Beijing, China.

Guimaraes, C., Kim, S., Silva, C., and Cavaco-Paulo, A. (2011). "In situ laccase-assisted overdyeing of denim using flavonoids," Biotechnology Journal 6(10), 1272-1279. DOI: $10.1002 /$ biot.201100201

Heier, A., Blaas, W., Droß, A., and Wittkowski, R. (2002). "Anthocyanin analysis by HPLC/ESI-MS,” American Journal of Enology and Viticulture 53(1), 78-86. DOI: 10.1016/S0304-4238(01)00277-1

Huang, D. L., Chen, X. K., Xu, Y. Q., Sun, S. Q., and Lu, W. G. (2014). "Study on Panax notoginseng and its processed products by FTIR spectroscopy," Spectroscopy and Spectral Analysis 34(7), 1849-1852. DOI:10.3964/j.issn.1000-0593(2014)071849-04

Jung, J. C., and Park, O. S. (2009). "Synthetic approaches and biological activities of 4hydroxy-coumarin derivatives," Molecules 14(11), 4790-4803. DOI:

10.3390/molecules 14114790 
Li, Q. Y., Wu, Q. R., Lin, J. G., Liu, S. Z., and Wang, X. X. (2016). "Physiological and biochemical mechanism of wood rot fungi on heartwood extract of big fruit rosewood," Journal of Jiangxi Agricultural University 38(2), 327-331. DOI: $10.13836 / \mathrm{j} . \mathrm{jjau} .2016046$

Liu, H., and Li, J. (2010). "The study of the ecological problems of eucalyptus plantation and sustainable development in Maoming Xiaoliang," Journal of Sustainable Development 3(1), 197-201. DOI: 10.5539/jsd.v3n1p197

Marzouk, M. S., El-Toumy, S. A. A., Merfort, I., and Nawwar, M. A. M. (1999). "Polyphenolic metabolites of Rhamnus disperma," Phytochemistry (Oxford) 52(5), 943-946. DOI: 10.1016/s0031-9422(99)00262-9

Moiz, A., Ahmed, M. A., Kausar, N., Ahmed, K., and Sohail, M. (2010). "Study the effect of metal ion on wool fabric dyeing with tea as natural dye," Journal of Saudi Chemical Society 14(1), 69-76. DOI: 10.1016/j.jscs.2009.12.011

Morita, Z., Tanaka, T., and Motomura, H. (1986). "Diffusion/adsorption model of cellulose dyeing. I. The diffusion through never-dry cellulose," Journal of Applied Polymer Science 31(3), 777-789. DOI: 10.1002/app.1986.070310303

Peters, L., Stevens, C. B., Budding, J., Burdett, B. C., and Sykes, J. A. W. (2008). "The effect of solvents in wool dyeing," Coloration Technology 76(9), 543-550. DOI: 10.1111/j.1478-4408.1960.tb02396.x

Puvaneswari, N., Muthukrishnan, J., and Gunasekaran, P. (2006). "Toxicity assessment and microbial degradation of azo dyes," Indian Journal of Experimental Biology 44(8), 618-626.

Romani, A., Vignolini, P., Tanini, A., Pampaloni, B., and Heimler, D. (2010). "HPLC/DAD/MS and antioxidant activity of isoflavone-based food supplements," Natural Product Communications 5(11), 1775-1780. DOI: 10.1002/minf.201000096

Saha Tchinda, J. B., Pétrissans, A., Molina, S., Ndikontar, M. K., Mounguengui, S., Dumarçay, S., and Gérardin, P. (2014). "Study of the feasibility of a natural dye on cellulosic textile supports by red padouk (Pterocarpus soyauxii) and yellow movingui (Distemonanthus benthamianus) extracts," Industrial Crops and Products 60, 291297. DOI: $10.1016 /$ j.indcrop.2014.06.029

Sammani, M. S., Clavijo, S., Portugal, L., Ruth, S., Seddik, H., and Víctor, C. (2017). "Use of multiresponse statistical techniques to optimize the separation of diosmin, hesperidin, diosmetin and hesperitin in different pharmaceutical preparations by high performance liquid chromatography with UV-DAD," Talanta 167, 695-702. DOI: 10.1016/j.talanta.2017.02.069

Sun, J., Liu, Y. P., Yu, Y. X., and Fang, W. J. (2012). "The effect of dyeing process on the dyeing rate of eucalyptus veneer," Practical Forestry Technology (12), 76-77. DOI: $10.13456 /$ j.cnki.lykt.2012.12.003

Tian, Z., Wan, M., Wang, Z., and Wang, B. (2011). "The preparation of genistein and LC-MS/MS on-line analysis," Drug Development Research 8(40), 1004-1014. DOI: 10.1002/ddr.10332

Umbreen, S., Ali, S., Hussain, T., and Nawaz, R. (2008). "Dyeing properties of natural dyes extracted from turmeric and their comparison with reactive dyeing," Research Journal of Textile and Apparel 12(4), 1-11. DOI: 10.1108/RJTA-12-04-2008-B001 
Wang, C. C., Deng, S. Q., and Lin, J. G. (2018). "Dyeing properties of acid dyes in Cunninghamia lanceolata plantations," Journal of Forestry and Environment 38(1), 111-117. DOI: 10.13324/j.cnki.jfcf.2018.01.018

Wang, F. L., Li, S., Sun, Y. X., Han, H. Y., Zhang, B. X., and Hu, B. Z. (2017). “Ionic liquids as efficient pretreatment solvents for lignocellulosic biomass," RSC Advances 7, 47990-47998. DOI: 10.1039/C7RA08110C

Wang, Y. T., Cao, L. F., Yang, Z., Yan, B., and Zhang, L. J. (2016). "Research on the medicinal effective component and characterization of virus-free breeding and sulfur smoked Qi chrysanthemum based on FTIR and FT-Raman," Spectroscopy and Spectral Analysis 36(9), 2780-2783. DOI: 10.3964/j.issn.1000-0593(2016)09-278004

Wang, Y., Catana, F., Yang, Y., Roderick, R., and Van Breemen, R. B. (2002). “An LCMS method for analyzing total resveratrol in grape juice, cranberry juice, and in wine," Journal of Agricultural and Food Chemistry 50(3), 431-435. DOI: 10.1021/jf010812u

Xie, J., Sun, B., Wang, S., and Ito, Y. (2009). "Isolation and purification of nootkatone from the essential oil of fruits of Alpinia oxyphylla Miquel by high-speed countercurrent chromatography," Food Chemistry 117(2), 375-380. DOI: 10.1016/j.foodchem.2009.04.011

Xie, J., Zhang, Y., Wang, W., and Hou, J. (2014). "Identification and simultaneous determination of glycyrrhizin, formononetin, glycyrrhetinic acid, liquiritin, isoliquiritigenin, and licochalcone A in licorice by LC-MS/MS," Acta Chromatographica 26(3), 507-516. DOI: 10.1556/achrom.26.2014.3.9

Xu, G. K., Qin, X. Y., Wang, G. K., Xie, G. Y., Li, X. S., and Sun, C. Y. (2017). "Antihyperglycemic, antihyperlipidemic and antioxidant effects of standard ethanol extract of, bombax ceiba, leaves in high-fat-diet- and streptozotocin-induced type 2 diabetic rats," Chinese Journal of Natural Medicines 15(3), 168-177. DOI: 10.1016/S1875-5364(17)30033-X

Xu, H., Yaguchi, H., and Shioiri, S. (2001). "Testing CIELAB-based color-difference formulae using large color differences," Optical Review 8(6), 487-494. DOI: 10.1007/bf02931740

Yang, Y. Y., Wu, G. X., and Chen, D. M. (2018). "Antibacterial properties and design elements of silk knitted underwear dyed by hematoxylin plant dyes," Silk 55(7), 2127. DOI: 10.3969/j.issn.1001-7003.2018.07.004

Yang, Y. Y. (2019). Components, Stability and Physiological Activity of the Pigment of Dalbergia bariensis Heartwood, Master's Thesis, Guangxi University, Beijing, China. (In Chinese) DOI: 10.27034/d.cnki.ggxiu.2019.000306

Ye, X., Peng, Y., Niu, Z., Luo, X., and Zhang, L. (2018). "Novel approach for the rapid screening of banned aromatic amines in dyed textiles using a chromogenic method," Analytical and Bioanalytical Chemistry 410(11), 2701-2710. DOI: 10.1007/s00216018-0941-X

Zhang, P., Wei, Y. X., Liu, Y., Chen, Y., Gao, J. M., and Fan, Y. M. (2018). "Hair color composition of heartwood extracts from rosewood and its effect on color," Chemistry and Industry of Forest Products 38 (5), 81-88. DOI: 10.3969/j.issn.0253-2417

Zhao, Q., Feng, H., and Wang, L. (2014). "Dyeing properties and color fastness of cellulase-treated flax fabric with extractives from chestnut shell," Journal of Cleaner Production 80, 197-203. DOI: 10.1016/j.jclepro.2014.05.069 
Zhu, T., Liu, S. Z., Ren, K., Chen, J. B., Lin, J. G., and Li, J. (2018). “Colorability of dyed wood veneer using natural dye extracted from Dalbergia cochinchinensis with different organic solvents," BioResources 13(4), 7197-7211. DOI:

10.15376/biores.13.4.7197-7211

Article submitted: April 17, 2020; Peer review completed: September 5, 2020; Revised version received and accepted; September 23, 2020; Published: October 12, 2020.

DOI: $10.15376 /$ biores.15.4.8925-8943 